\title{
Development and validation of stability-indicating RP-UPLC method for simul- taneous estimation of thiocolchicoside and aceclofenac in combined dosage form
}

\author{
*Paramasivam Balan ${ }^{1}$, Nagappan Kannappan ${ }^{2}$ \\ ${ }^{1}$ Research Scholar, Faculty of Pharmacy, PRIST University, Thanjavur, Tamil Nadu, India \\ ${ }^{2}$ Associate Professor, Department of Pharmacy, Annamalai University, Annamalai Nagar, Tamil Nadu, India
}

\begin{abstract}
A stability indicating RP-UPLC method was developed and validated for the simultaneous determination of Thiocolchicoside (TCC) and Aceclofenac (ACF) in tablet dosage form. The chromatographic separation was carried out by Thermo Scientific UPLC Instrument, Accela 1250 Pump, auto sampler with PDA detector, using column Thermo Scientific hypersil gold $C_{18}$, $(50 \times 2.1 \mathrm{~mm})$ particle size $1.9 \mu \mathrm{m}$ using $5 \%$ ammonium acetate buffer and methanol in the ratio of $40: 60, \mathrm{pH}$ was adjusted to 5 with ortho phosphoric acid as mobile phase at a flow rate of $250 \mu \mathrm{l} / \mathrm{min}$ with the detection at $276 \mathrm{~nm}$. The run times of the TCC and ACF were about 0.697 and 1.125 minutes, respectively. The detector response is linear from $4.8 \mu \mathrm{gg} / \mathrm{ml}$ to $7.2 \mu \mathrm{g} / \mathrm{ml}$ and $63.8 \mu \mathrm{g} / \mathrm{ml}$ to $96 \mu \mathrm{\mu g} / \mathrm{ml}$ concentrations for TCC and ACF respectively. The linear regression equation was found to be $y=20620 x-677.68\left(r^{2}=0.9996\right)$ for TCC and $y=50931 \mathrm{x}-319.3\left(\mathrm{r}^{2}=0.9997\right)$ for ACF. The detection limit and quantification limit was $0.076 \mu \mathrm{g}$ and $0.23 \mu \mathrm{g}$ for TCC and $0.27 \mu \mathrm{g}$ and $0.71 \mu \mathrm{g}$ for ACF. The percentage of assay of TCC and ACF were about $99.50 \%$ and $99.96 \%$ respectively. The stability indicating capability was established by forced degradation experiments. The method was satisfactorily validated as per the ICH guidelines
\end{abstract}

Key Words: Thiocolchicoside, aceclofenac, stability indicating, method development, RP-UPLC, validation.

\section{INTRODUCTION}

Thiocolchicoside (TCC) is chemically named as $N$-[(7S)-3( $\beta$-D-Glucopyranosyloxy)- 1,2-dimethoxy -10- (methylsulfanyl) -9- oxo-5,6,7,9-tetrahydrobenzo[ $\alpha$ ]heptalen-7-yl] acetamide (figure 1). It is a semi-synthetic derivative of the natural colchicoside compound. It is an antiinflammatory, muscle relaxant and analgesic drug and also used topically for the treatment of muscular spasms and rheumatologic disorders (O'Neil, 2006; Indian Pharmacopoeia, 2010).

Aceclofenac (ACF) [[2-[2-[(2,6-dichlorophenyl) amino]phenyl]acetyl] oxy acetic acid] (figure 2). It is used as an effective non-steroidal anti-inflammatory drug (NSAID) derived from the phenyl acetic acid with pronounced anti-inflammatory, analgesic, antipyretic activity and treatment of rheumatoid arthritis and ankylosing spondylitis (Indian Pharmacopoeia, 2007; Saraf et al, 2006).

In Literature survey, simple UV spectrophotometric (Qin et.al, 2006; Rachana and Gupta, 2010; Acharjya et al., 2010), HPLC method (Rosso and Zuccaro, 1998; Sutherland et al., 2002; Hilmi and Bayram, 2007; Dhaneshwar et al., 2011; Suganthi et al., 2013; Nyola et al., 2012) and HPTLC methods (Ragehy et al., 2003; Sunita et al., 2011; Rajput et al., 2013) were reported for aceclofenac and thiocolchicoside individually and in combination with other drugs. Extensive literature survey revealed that no stability indicating RP-UPLC method has been reported for simultaneous determination of thiocolchicoside and aceclofenac in combined dosage form.

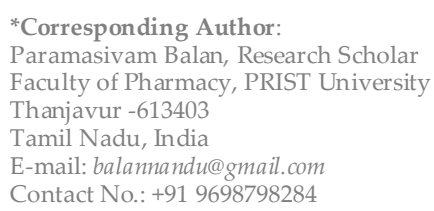

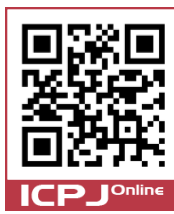

\section{MATERIALS AND METHODS}

\section{Materials}

TCC was obtained from Firstmed Therapeutics Pvt. Ltd, Pondicherry and ACF was obtained from Ideal Analytical \& Research Institution, Pondicherry. Water (HPLC grade), Acetonitrile (HPLC grade), Methanol (HPLC grade) and Ammonium Acetate were of Analytical grade purchased from Merck. The commercial combination of TCC $(8 \mathrm{mg})$ and ACF $(100 \mathrm{mg})$ was purchased from drug store.

\section{Instrumentation}

A Thermo Scientific Ultra performance liquid chromatography (UPLC) Instrument, Accela 1250 Pump and auto sampler with PDA detector and Thermo hypersil gold $\mathrm{C}_{18}$ column $(50 \times 2.1 \mathrm{~mm})$ particle size $1.9 \mu \mathrm{m}$. The UPLC system was operational with CHROMQUEST software for data processing. Sartorius analytical micro balance, Ultra sonicator (DC1500H MRC), pH meter (MKVI Systronics), micropipettes and micro-pore filtration set etc. were also used.

\section{Chromatographic Con ditions}

The analysis was carried out on Thermo Scientific Hypersil gold $\mathrm{C}_{18}$ Column $(50 \times 2.1 \mathrm{~mm}$, particle size $1.9 \mu \mathrm{m})$, the mobile phase containing $5 \%$ ammonium acetate buffer and methanol (40:60), $\mathrm{pH}$ adjusted to 5 with ortho phosphoric acid was found to resolve TCC and ACF. The mobile phase was filtered on 0.22 micron membrane filter and sonicated for $15 \mathrm{~min}$. The injection volume was $10 \mu \mathrm{l}$. The flow rate was set to be $250 \mu \mathrm{l} / \mathrm{min}$. The wavelength was selected at $276 \mathrm{~nm}$ with PDA detector for analysis. All determinations were performed at constant column temperature $\left(25 \pm 2^{\circ} \mathrm{C}\right)$. The total run time of the analysis was $3 \mathrm{~min}$. The retention time of the TCC and ACF was $0.697 \mathrm{~min}$ and $1.125 \mathrm{~min}$ respectively and the chromatogram was given in figure 3 . 
<smiles>COc1c(O[C@@H]2O[C@H](CO)[C@@H](O)[C@H](O)[C@H]2O)cc2c(c1OC)-c1ccc(SC)c(=O)cc1[C@@H](NC(C)=O)CC2</smiles>

Figure 1: Chemical Structure of Thiocolchicoside.

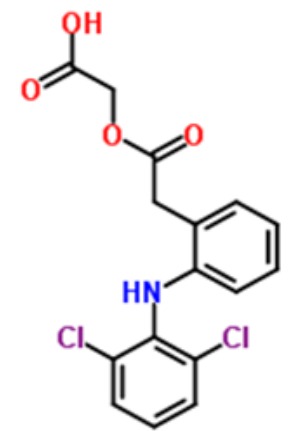

Figure 2: Chemical Structure of Aceclofenac.

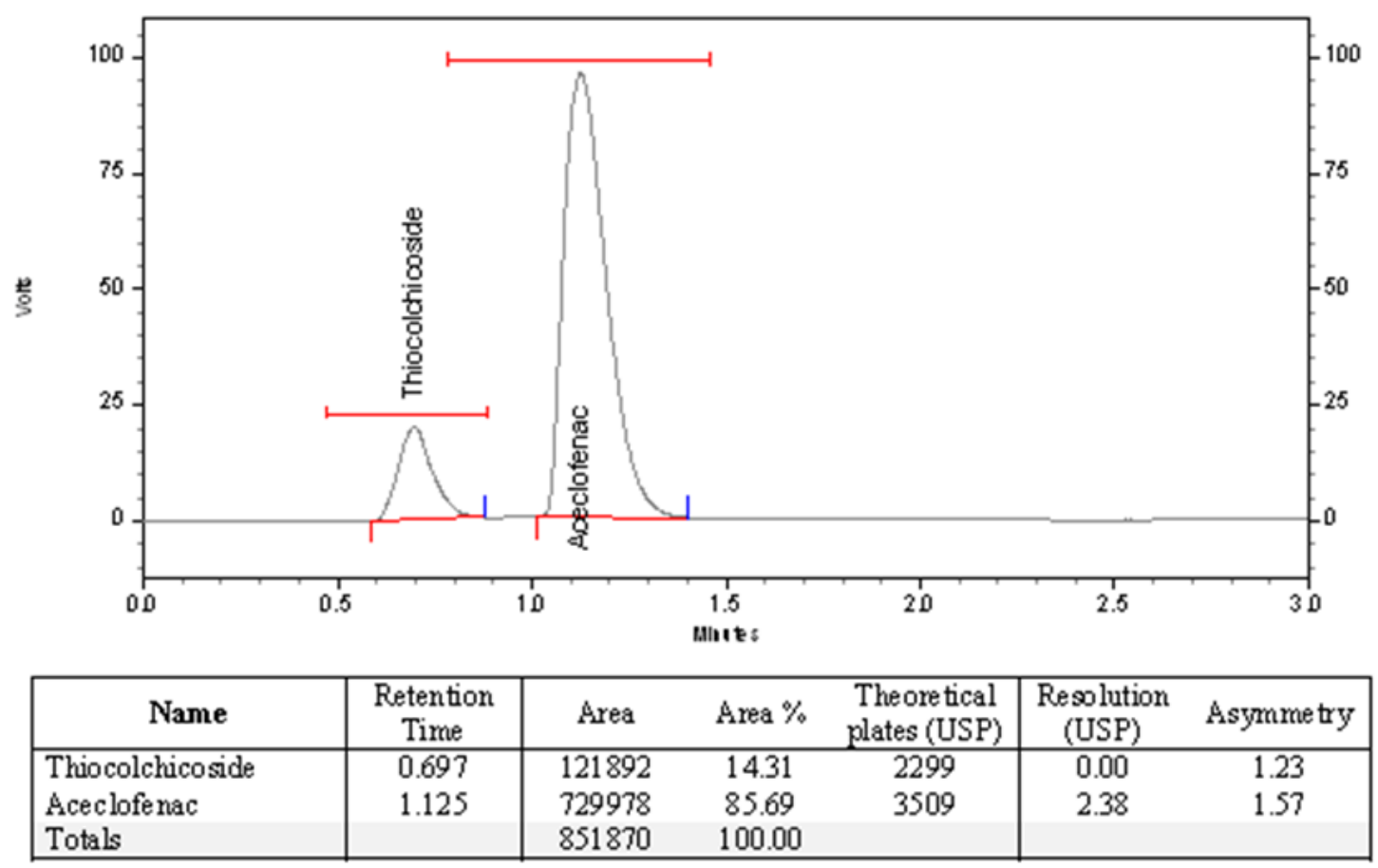

Figure 3: UPLC - Chromatogram of TCC and ACF.

\section{Preparation of standard solution}

The standard stock solutions were prepared by transferring $16 \mathrm{mg}$ of TCC and $200 \mathrm{mg}$ of ACF working standards in $25 \mathrm{ml}$ volumetric flask and dissolved with methanol upto the mark. From the standard stock solution $1 \mathrm{ml}$ was taken into $100 \mathrm{ml}$ flask, further diluted with mobile phase to get the final concentration of $6.4 \mu \mathrm{g} / \mathrm{ml}$ of TCC and 80 $\mu \mathrm{g} / \mathrm{ml}$ of $\mathrm{ACF}$.

\section{Preparation of sample Solution}

Accurately weighed 10 tablets were triturated with a mortar and pestle. An amount equivalent to $16 \mathrm{mg}$ of TCC and $200 \mathrm{mg}$ of ACF sample was transferred to a $25 \mathrm{ml}$ clean volumetric flask, diluted with $10 \mathrm{ml}$ methanol and sonicate to dissolve it completely and made the volume with the same solvent. Further $1 \mathrm{ml}$ of the TCC and ACF of above stock solution was taken into a $100 \mathrm{ml}$ volumetric flask, diluted with mobile phase and analyzed under optimized chromatographic conditions. The chromatogram was eluted. The assay results were shown in Table.1

\section{Forced Degradation Studies}

It is a process in which the natural degradation rate of a pharmaceutical formulation is increased by applying the additional stress. UPLC method is used to separate, detect, and quantify the various drug related degradation substances. The stock solution of the sample was treated with various degradation conditions (Blessy et al., 2013; Ngwa, 2010) such as acidic (0.1N HCL, $60^{\circ} \mathrm{C}, 24$ hours), alkaline $\left(1 \mathrm{~N} \mathrm{NaOH}, 60^{\circ} \mathrm{C}, 24\right.$ hours), oxidization ( $3 \%$ $\mathrm{H}_{2} \mathrm{O}_{2}, 60^{\circ} \mathrm{C}, 24$ hours), thermal $\left(60^{\circ} \mathrm{C}, 24\right.$ hours) and sunlight (24 hours). Both TCC and ACF were found to be highly sensitive to acidic, alkali and oxidative degradation. The peak area and assay value were dropped in all the above mentioned conditions. The results of forced degradation studies were given in table 2 and shown in figure 4-8. However no major degradation was found in thermal condition and under sunlight.

\section{Method Validation}

The developed method was validation as per ICH guidelines (ICH-Guidelines, 1996). The validation parameters are 


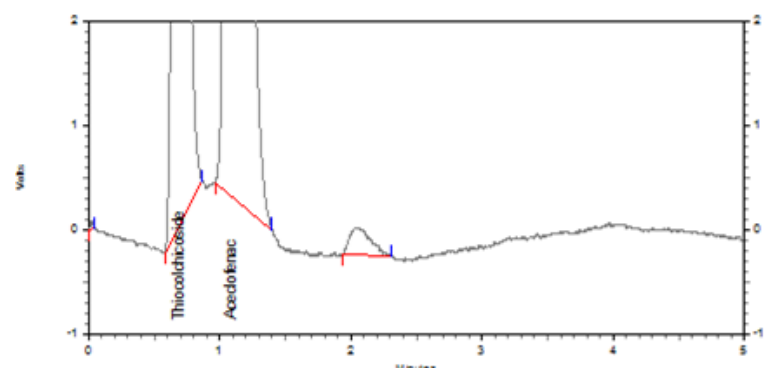

Figure 4: Acid degradation.

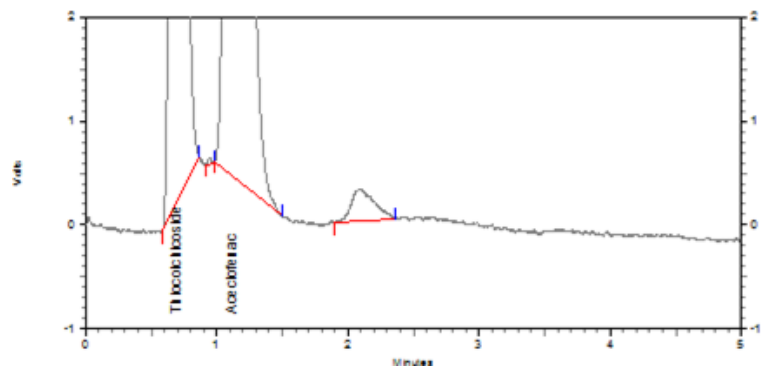

Figure 6: Peroxide degradation.

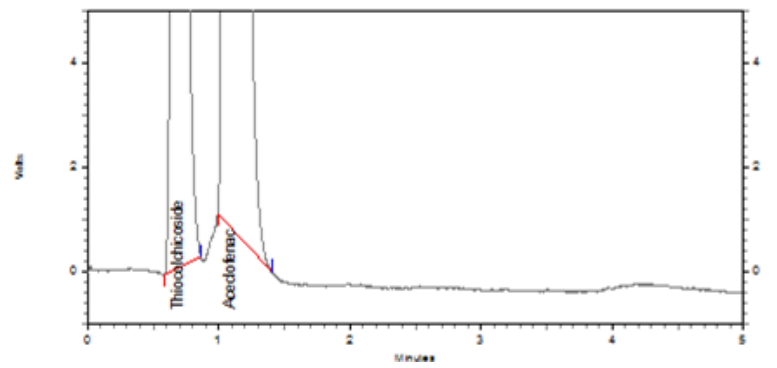

Figure 8: Sunlight degradation.

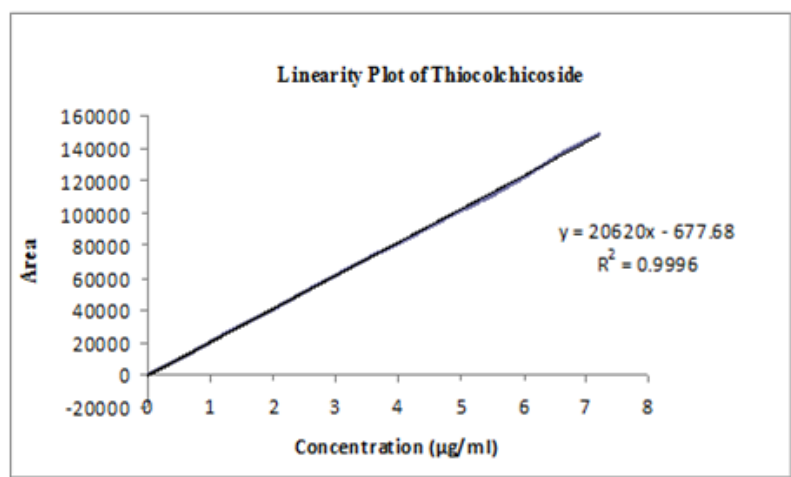

Figure 10: Linearity Curve for Thiocolchicoside.

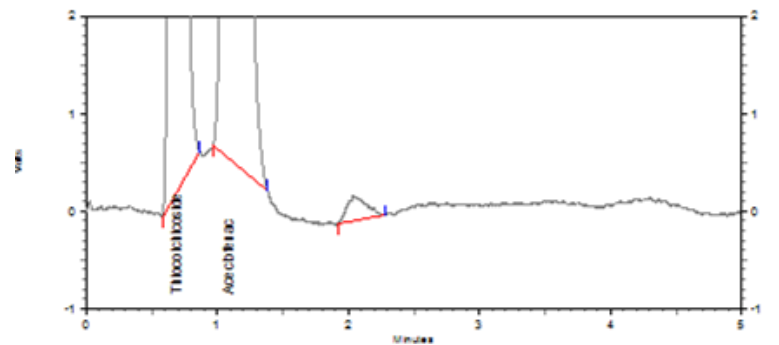

Figure 5: Alkali degradation.

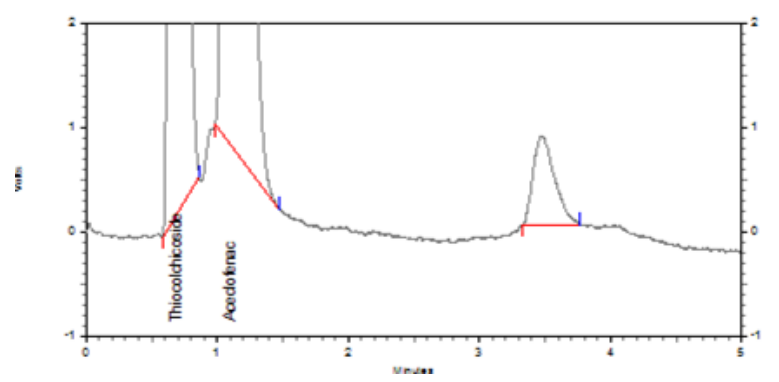

Figure 7: Thermal degradation.

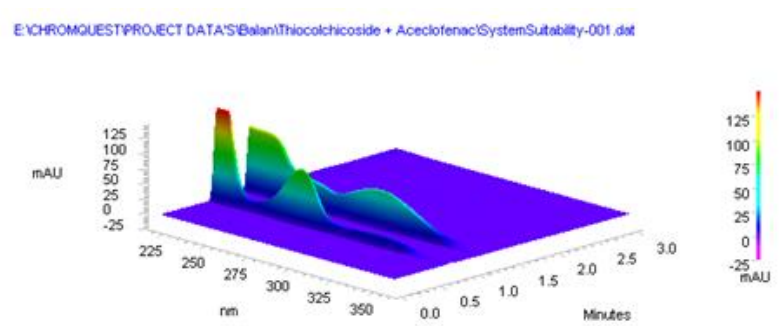

Figure 9: System Suitability 3D Picture of TCC and ACF.

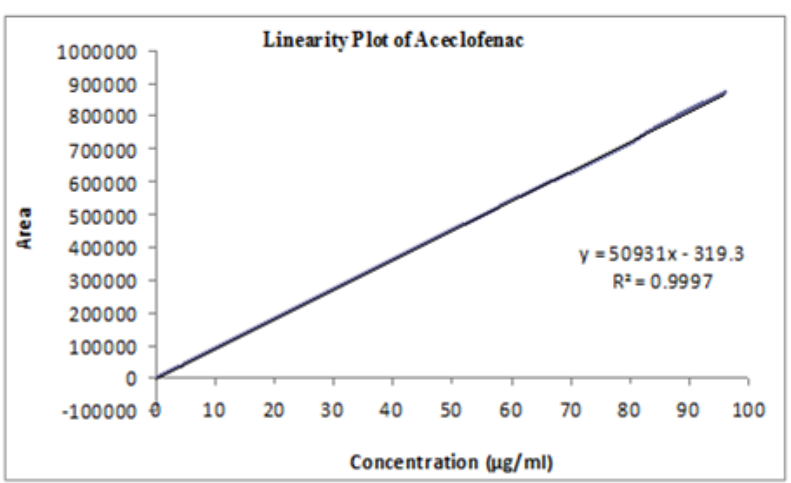

Figure 11: Linearity Curve for Aceclofenac. 
Table 1: Assay of TCC and ACF.

\begin{tabular}{cccc}
\hline Formulation & Drug & $\begin{array}{c}\text { Label } \\
\text { Claim(mg) }\end{array}$ & Purity (\%) \\
& Thiocolchicoside & 8 & 99.50 \\
Tablet & Aceclofenac & 100 & 99.96 \\
\hline
\end{tabular}

Table 3: System Suitability Parameters.

\begin{tabular}{ccc}
\hline Parameters & TCC & ACF \\
\hline Resolution Factor & --- & 2.38 \\
Theoretical Plates & 2299 & 3509 \\
Asymmetric Factor & 1.23 & 1.57 \\
Retention Time & 0.697 & 1.125 \\
Standard Deviation & 1360 & 3419 \\
RSD & 1.13 & 0.47 \\
DL & $0.076 \mu \mathrm{g}$ & $0.27 \mu \mathrm{g}$ \\
QL & $0.23 \mu \mathrm{g}$ & $0.71 \mu \mathrm{g}$ \\
\hline
\end{tabular}

Table 2: Forced Degradation Studies.

\begin{tabular}{|c|c|c|c|c|c|c|c|c|c|}
\hline \multirow{2}{*}{$\begin{array}{c}\text { Degradation } \\
\text { Parameters }\end{array}$} & \multirow{2}{*}{$\begin{array}{c}\text { Degradation } \\
\text { Time (hr) }\end{array}$} & \multicolumn{2}{|c|}{$\begin{array}{c}\text { Standard Peak } \\
\text { Area }\end{array}$} & \multicolumn{2}{|c|}{$\begin{array}{l}\text { Peak Area } \\
\text { Product }\end{array}$} & \multicolumn{2}{|c|}{$\begin{array}{c}\% \text { of } \\
\text { Recovery }\end{array}$} & \multicolumn{2}{|c|}{$\%$ of Degradation } \\
\hline & & TCC & ACF & TCC & ACF & TCC & ACF & TCC & ACF \\
\hline $\begin{array}{c}\text { Acid Degradation } \\
\left(0.1 \mathrm{~N} \mathrm{HCl}, 60^{\circ} \mathrm{C}\right)\end{array}$ & 24 & 120807 & 725077 & 102255 & 590482 & 85.16 & 81.95 & 14.84 & 18.05 \\
\hline $\begin{array}{l}\text { Alkali Degradation } \\
\left(0.1 \mathrm{~N} \mathrm{NaOH}, 60^{\circ} \mathrm{C}\right)\end{array}$ & 24 & 120807 & 725077 & 106146 & 630717 & 88.4 & 87.53 & 11.6 & 12.47 \\
\hline $\begin{array}{l}\text { Peroxide Degradation } \\
\quad\left(3 \% \mathrm{H}_{2} \mathrm{O}_{2}, 60^{\circ} \mathrm{C}\right)\end{array}$ & 24 & 120807 & 725077 & 100650 & 580365 & 83.83 & 80.54 & 16.17 & 19.46 \\
\hline $\begin{array}{l}\text { Thermal Degradation } \\
\left(\text { Oven, } 60^{\circ} \mathrm{C}\right)\end{array}$ & 24 & 120807 & 725077 & 115647 & 674391 & 96.32 & 93.59 & 3.68 & 6.41 \\
\hline Sunlight & 24 & 120807 & 725077 & 117648 & 672256 & 97.98 & 93.3 & 2.02 & 6.7 \\
\hline
\end{tabular}

Table 4: Linearity.

\begin{tabular}{ccccc}
\hline & \multicolumn{2}{c}{ TCC } & \multicolumn{2}{c}{ ACF } \\
\hline Level & $\begin{array}{c}\text { Concentration } \\
(\mu \mathrm{g} / \mathrm{ml})\end{array}$ & Area & $\begin{array}{c}\text { Concentration } \\
(\mu \mathrm{g} / \mathbf{m l})\end{array}$ & Area \\
\hline $\mathbf{8 0} \%$ & 4.8 & 97361 & 63.8 & 575039 \\
$\mathbf{9 0} \%$ & 5.4 & 109148 & 72 & 644985 \\
$\mathbf{1 0 0} \%$ & 6 & 122625 & 79.9 & 715732 \\
$\mathbf{1 1 0} \%$ & 6.6 & 136417 & 87.9 & 804480 \\
$\mathbf{1 2 0} \%$ & 7.2 & 148974 & 96 & 872634 \\
\hline
\end{tabular}

Table 6: Precision data.

\begin{tabular}{ccccc}
\hline \multirow{2}{*}{ Drug } & \multicolumn{2}{c}{ Intraday assay } & \multicolumn{2}{c}{ Inter day assay } \\
\cline { 2 - 5 } & \% Obtained & \% RSD & \% Obtained & \% RSD \\
\hline TCC & 100.6 & 0.42 & 100.41 & 0.81 \\
ACF & 100.3 & 0.16 & 99.91 & 0.22 \\
\hline
\end{tabular}

linearity, accuracy, precision, limit of detection (LOD), limit of quantitation (LOQ) and robustness.

\section{System Suitability}

The six replicated injections were made in the standard solutions of both TCC and ACF and system suitability parameters such as theoretical plates (USP), resolution (USP) and asymmetry factor were evaluated. The results of the system suitability parameters were given in table 3 . The 3D chromatogram was given in figure 9.
Table 5: Accuracy (Recovery) Data.

\begin{tabular}{ccccc}
\hline \multirow{2}{*}{ Parameters } & \multicolumn{2}{c}{ TCC } & \multicolumn{2}{c}{ ACF } \\
\cline { 2 - 5 } & \% Recovery & \% RSD & \% Recovery & \% RSD \\
\hline $\mathbf{8 0 \%}$ & 100.55 & 0.9 & 100.8 & 0.42 \\
$\mathbf{1 0 0 \%}$ & 100.19 & 0.82 & 99.8 & 0.52 \\
$\mathbf{1 2 0} \%$ & 100.38 & 0.71 & 100.12 & 0.47 \\
\hline
\end{tabular}

Table 7: Robustness data.

\begin{tabular}{cccccc}
\hline & & \multicolumn{2}{c}{ Retention time } & \multicolumn{2}{c}{ Area $\left(\mu v^{2} \mathbf{s e c}\right)$} \\
\cline { 3 - 6 } Factors & Level & TCC & ACF & TCC & ACF \\
\hline Standard & $250 \mu \mathrm{l} / \mathrm{min}$ & 0.697 & 1.23 & 120807 & 725077 \\
& $225 \mu \mathrm{l} / \mathrm{min}$ & 0.728 & 1.145 & 111163 & 640224 \\
Flow rate & $275 \mu \mathrm{l} / \mathrm{min}$ & 0.651 & 1.06 & 111043 & 682621 \\
& $274 \mathrm{~nm}$ & 0.7 & 1.12 & 116383 & 712689 \\
Wavelength & $278 \mathrm{~nm}$ & 0.7 & 1.12 & 122745 & 732359 \\
Analyst & $\mathrm{I}$ & 0.698 & 1.25 & 120912 & 725062 \\
& $\mathrm{II}$ & 0.697 & 1.24 & 120876 & 725152 \\
\hline
\end{tabular}

\section{Linearity}

Linearity was demonstrated from five different concentration levels for both TCC and ACF, which were found to be linear in the range of $4.8 \mu \mathrm{g} / \mathrm{ml}$ to $7.2 \mu \mathrm{g} / \mathrm{ml}$ and $63.8 \mu \mathrm{g} / \mathrm{ml}$ to $96 \mu \mathrm{g} / \mathrm{ml}$, respectively. The values were given in Table 4. Correlation coefficient for TCC and ACF was 0.9996 and 0.9997 respectively. The calibration curves were shown in the figure10 and 11.

Accuracy (Recovery Studies)

To check the degree of accuracy of the method, the recovery studies were performed by standard addition method at 
$80 \%, 100 \%$ and $120 \%$. Known amounts of standard mixture of TCC and ACF were added to pre-analyzed samples and were subjected to the proposed UPLC method. Results of recovery studies were shown in table 5 .

\section{Precision}

Intraday precision and inter-day precision were evaluated by carrying out six independent sample preparations $(6.4 \mu \mathrm{g} / \mathrm{ml}$ of TCC and $80 \mu \mathrm{g} / \mathrm{ml}$ of ACF) from a single lot formulation. Percentage relative standard deviation (\%RSD) was calculated. The results for precision were given in table 6 .

\section{Robustness}

To evaluate the robustness of the developed RP-UPLC, small deliberate variations in the optimized method parameters were done. The effect of $\pm 2 \%$ change in flow rate, $\pm 2 \mathrm{~nm}$ wavelength and 2 different analysts on the retention time and area were studied. The results of robustness were tabulated in table 7 .

\section{Detection Limit (DL) and Quantitation Limit $(Q L)$}

The Detection Limit (DL) is the lowest concentration of analyte in a sample that can be detected. The quantification limit $(\mathrm{QL})$ is defined as the lowest concentration of the substance that can be quantified with acceptable precision and accuracy. The detection limit and Quantitation limit were calculated as DL $=3.3 \times$ Syx /slope and QL $=10.0 \times$ Syx / Slope, here Syx is residual variance due to regression. The DL and QL values were given in table 3 .

\section{RESULTS AND DISCUSSION}

To develop a suitable UPLC method for analysis of the drugs in pharmaceutical formulation, initially tests were carried out to select optimum conditions. After quite a lot of trials were tested by using various proportions of solvents including buffer and acetonitrile. The goal of this study was to develop a rapid UPLC method for the analysis of TCC and ACF in a finished combined tablet dosage form using a ammonium acetate buffer and methanol in the ratio of 40:60 as mobile phase at a flow rate of $250 \mu \mathrm{l} / \mathrm{min}$, hypersil $\mathrm{C}_{18}(50 \times 2.1 \mathrm{~mm})$, particle size $1.9 \mu \mathrm{m}$ column with the PDA detection at $276 \mathrm{~nm}$. The retention time was found to be 0.697 and $1.125 \mathrm{~min}$ for TCC and ACF, respectively. The linear regression equations were $y=20620 x-677.68\left(r^{2}=0.9996\right)$ for TCC, $y=$ $50931 x-319.3\left(\mathrm{r}^{2}=0.9997\right)$ for ACF. The developed method found to be accurate and precise; the RSD values are less than 1 . The stability indicating capability was established by forced degradation experiments. The percentage of assay for TCC and ACF were about $99.50 \%$ and $99.96 \%$, respectively.

\section{CONCLUSION}

The developed method was simple, rapid, and accurate for simultaneous determination of thiocolchicoside and aceclofenac in combined tablet dosage form. The mobile phase is simple and easy to prepare and also economical. This proposed method can be easily adopted for routine analysis of Thiocolchicoside and Aceclofenac in combined dosage form.

\section{ACKNOWLEDGEMENT}

The authors are very much grateful to PRIST University, Thanjavur, India and Ideal Analytical \& Research Institution, Puducherry, India for providing all the facilities to perform the research work.

\section{REFERENCES}

Acharjya S.K., Mallick, P., Panda P. and Annapurna M.M.

(2010).Spectrophotometric methods for the determination of thiocolchicoside in bulk and pharmaceutical dosage forms. J Pharm Educ Res, Vol. 1, Issue No. 1.

Blessy M.et.al, (2013) Development of forced degradation and stability indicating studies of drugs - A review, J. Pharm. Anal. [DOI]

Dhaneshwar, S.R., Raut, K.O. and Bhusari V.K. (2011). Validated HPLC method for simultaneous estimation of paracetamol, aceclofenac and thiocolchicoside in bulk drug and formulation, Research Journal of Pharmaceutical, Biological and Chemical Sciences. Volume 2, Issue 2 , page $435-445$.

Hilmi I, Bayram BO, (2007). Validation of analytical procedure for the determination of Tiocolchicoside drug by HPLC.Salon1 A \& B (Intercontinental at the Plaza); 281.

ICH of Technical requirements for the registration of Pharmaceutical for Human Use (ICH) Q2b. Validation Analyticla Procedures Methodology (1996)

ICH-Guidelines Q2A, (1995). Validation of Analytical Procedures: Definition and terminology Geneva, Switzerland. 68-76.

Indian Pharmacopoeia (2007), Volume II. Govt. of India, New Delhi: Ministry of Health and Family Welfare; 681-683.

Ngwa, G. (2010) Forced Degradation as an Integral part of HPLC Stability - Indicating Method Development, Drug Delivery Technology, June, Vol 10, No.5

Nyola N.K., Jeyabalan, G.S., Kalra N., Parveen, G., Choudhary, S. (2012). Development and Validation of a RP-HPLC Method for Simultaneous Estimation of Diacerein and Aceclofenac in Pharmaceutical Dosage Form Journal of Pharmaceutical Analysis; 1(1):1-8.

O'Neil M. J. (2006) The Merck Index, An Encyclopedia Of Chemical, Drugs and Biologicals, Maryadele J.O. Neil.Eds, 14th edition, Merck Research Lab, Division of Merck and co. Inc., Whitehouse Station, NJ,1603.

Qin L, Christine LC, Greg EC. (2006) Ultraviolet absorbance detection of colchicine and related alkaloids on a capillary electrophoresis microchip. Anal Chim Acta.; 572: 205-211. [DOI]

Rachana RJ, Gupta KR. (2010) UV-Spectrophotometric determination of Thiocolchicoside in capsule. Der Pharma Chemica; 2(2):384-391.

Ragehy NA, Ellaithy MM, Ghobashy M.A. (2003) Determination of thiocolchicoside in its binary mixtures (thiocolchicoside-glafenine and thiocolchicoside-floctafenine) by TLC- densitometry. Il Farmaco.; 58: 463-468. [DOI]

Rajput, D.K,. Atul A. Shirkhedkar, Jyoti K. Rajput, Harun M. Patel, and Sanjayj.Surana. (2013) Stability Studies of Thiocoldhicoside in Bulk and Capsules Using RP-HPTLC / Densitometry. Journal of Analytical Methods in Chemistry. Volume 2013, Article ID 142628. [DOI]

Rosso A, Zuccaro S. (1998). Determination of alkaloids from the colchicines family by reversed-phase High-Performance Liquid Chromatography. J Chromat A; 825:96-101. [DOI]

Saraf S., Garg G., Singh D., Saraf S. (2006) Aceclofenac: A Potent NonSteroidal Anti-Inflammatory Drug, Pharmainfo.net, Vol. 4 Issue 3.

Suganthi A, T.K Ravi, (2013) Application of Stability - Indicating RP-HPLC Method for the Simultaneous Estimation of Thiocolchicoside and Aceclofenac in Pharmaceutical Dosage Form. American Journal of PharmTech Research, 3(5): 327-337.

Sunita P.T., Bhusari, Vidhya K.; Dhaneshwar, Sunil R. (2011). Validated HPTLC Method for Simultaneous Estimation of Thiocolchicoside and Aceclofenac in bulk drug and Formulation. International journal of Pharma \& Bio Sciences, Vol. 2 Issue 2, pp. 482.

Sutherland FCW, Smit MJ., Herbst L, Hundt HKL, et al. (2002). Highly specific and sensitive liquid dhromatography-tandem mass spectrometry method for the determination of 3- desmethylthiocolchicine in human plasma as analyte for the assessment of bioequivalence after oral administration of thiocolchicoside. J Chromat A.; 949:71-77. [DOI] 